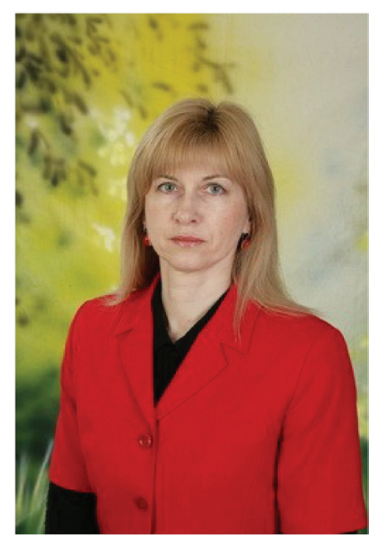

Skaistė Barkutè - filologijos mokslo krypties daktaré, nepriklausoma tyrèja

Moksliniai interesai: lietuvių literatūra (XIX a. ir XX a. pirmoji pusè), moralès filosofija ir literatūra, literatūros teologija El.paštas: sbarkute@yahoo.it

Skaistė Barkutė - PhD in Philology, independent researcher Research interests: Lithuanian literature (19 ${ }^{\text {th }}$ Century and first half of the $20^{\text {th }}$ Century), moral philosophy and literature, literary theology

E-mail: sbarkute@yahoo.it

\title{
Skaistè Barkutè
}

\section{SUTUOKTINIŲ TAR PUSAVIO SANTYKIŲ VAIZDAVIMO YPATUMAI MOTIEJAUS VALANČIAUS DIDAKTINËJE PROZOJE}

\begin{abstract}
Anotacija
Motiejus Valančius savo didaktinėje kūryboje nemažai dėmesio skiria sutuoktinių tarpusavio santykių vaizdavimui. Žemaičių vyskupo tikslas buvo ugdyti liaudi religine moraline dvasia. Valančiaus nuomone, sutuoktinių gerus santykius lemia vyro ir moters lygiateisiškumas, jų bendradarbiavimas ir vienodai prisiimta atsakomybė už vaikų auklèjimą. Kad šios sąlygos būtų įvykdytos, svarbus abiejų sutuoktinių socialinių-luominių, kultūrinių ir ypač tikybinių požymių atitikimas. Straipsnyje detaliai atskleidžiama, kaip meninėmis priemonėmis Valančius kuria didaktinį pamokymą vyro ir moters santykiu darnai užtikrinti.
\end{abstract}

PAGRINDINIAI ŽODŽIAI: Motiejus Valančius, didaktiniai kūriniai, sutuoktinių santykiai, lygiateisiškumas, blaivybè.

\begin{abstract}
Motiejus Valančius paid attention to the depiction of the relationship between a man and a woman (husband and wife) in his didactic creative work. The main aim of the Bishop of Samogitia was to educate people in the spirit of religion and morality. In Valančius' opinion, a good relationship between spouses is determined by equality between a man and a woman, cooperation, and equal responsibility for the children's upbringing. For this reason, the compatibility of social-caste, cultural and religious features between both spouses is important. The report reveals how Valančius created didactic precepts in order to create a harmonious relationship between a man and a woman. KEY WORDS. Motiejus Valančius, didactic writings, marital relationship, equality, abstinence.
\end{abstract}


Itvadas

XIX a. Žemaičių vyskupas Motiejus Valančius liaudį ugdyti ėmėsi per mokyklą, pamokslus, ganytojiškuosius laiškus, didaktinius prozos kūrinėlius. Pagrindinis Valančiaus prozos tikslas - ugdyti skaitytojus religine moraline dvasia (Merkys 1999, 718). Kaip pažymėjo Vytautas Merkys, Valančiaus liaudies ugdymo sistemos dalị sudarė elementarių žinių skleidimas apie tẻvams žinotiną pedagogiką, vaikų auginimą, tẻvų globą, sanitariją ir higieną (Merkys 1999, 326). Todèl nenuostabu, kad Valančius savo kūryboje nemažai dėmesio skyrẻ ir sutuoktinių tarpusavio santykių vaizdavimui. Harmoningi santykiai šeimoje, tarpusavio pagalba, abipusè meilè ir supratimas - tai lyg mokslas, kurị skleisti ėmėsi Žemaičiu vyskupas. Jo vaizduojami veikejjai bendraudami nepatiria didesnių psichologinių išgyvenimų. Jų tarpusavio santykius lemia kilmé, auklèjimas, socialinė aplinka. Tobuliems tarpusavio santykiams Valančius skatino siekti abiejų sutuoktinių socialinių-luominių, kultūrinių ir ypač tikybinių požymių atitikimo. Tik tokiu atveju tarp vyro ir moters vyksta dialogas, kuris ne visada imanomas, esant kokių nors skirtingumų (pvz., tikejjimo, tautybės, luomų). Kaip matysime iš toliau analizuojamų pavyzdžių, savo grožiniuose didaktiniuose kūriniuose meninėmis priemonėmis Valančius ugde moters ir vyro lygiateisiškumo šeimoje suvokimą, abiejų tẻvų atsakomybę už vaikų auklèjimą. Valančiaus požiūriui ị vyro ir moters santykius galima būtų pritaikyti hipotetišką Vytauto Kavolio formuluotę, kad XIX a. pažangiam vyrui tampa įmanoma ị savo tapatybės suvokimą įsileisti moters idejjas, o moteriai atsiranda galimybè suvokti vyro gyvenimą kaip savo gyvenimo dalį (Kavolis 2016, 102-103). Šio straipsnio objektas - Motiejaus Valančiaus didaktinejje prozoje vaizduojamų sutuoktinių santykiai. Atsižvelgiant i Valančiaus gyvenamąị laikotarpị ir susiklosčiusias istorines aplinkybes, keliamas tikslas - išanalizuoti didaktinę Valančiaus prozą ir išskirti vaizduojamų sutuoktinių santykių ryškiausius ypatumus. Straipsnyje pateikiami pavyzdžiai iš dviejų knygelių - „Vaikų knygelès“, paties Valančiaus tvirtinimu, parašytos ir išleistos 1864 m. (bibliografų nustatyta, kad ji išèjo 1868 m. ${ }^{1}$ ) ir „Paaugusių žmonių knygelès“, parašytos 1865 m., išleistos 1868 m., kurios turèjo tarp skaitytojų labai dideli pasisekimą ir kartu su kitais jo kūriniais („Žemaičių vyskupysté“, „Palangos Juze““, „Antano tretininko pasakojimai“, religiniai kūriniai) stiprino bei sąmonino lietuvių tautą (Trumpa 1975, XXX).

Bibliografiniai duomenys ir tekstų komentarai. In Motiejus Valančius. Raštai, t. 1. Vilnius: Lietuvių literatūros ir tautosakos institutas, 2001, 803. 
Geros šeimos pavyzdys

Lygiateisiškumas šeimoje pasižymi bendru sprendimų priimamumu, vienodu darbų pasiskirstymu, vienoda socialine padètimi. Apie lygiaverčius santykius šeimoje galima kalbèti, kai tiek vyras, tiek moteris jaučia abipusị įsipareigojimą šeimai ir gerbia vienas kitą. Štai kūrinèlyje „Plikbajoris“ („Paaugusių žmonių knygelë“) apie bendrą sutuoktiniu sutarimą ir lygiateisiškumą byloja tokie žodžiai: „Lygia dalia su moteria pasišnekejęs [tėvas - S. B.], nuvedè ji Kaunan ir pristatè prie gero kalvio“ (Valančius 2001, 131). Charakterio savybès ir tinkamo gyvenimo būdo dermè užtikrino vyro ir žmonos gražaus bendro sutarimo rezultatą. Gero vyro pavyzdys pateikiamas aprašant minèto kūrinio veikejją Staponą: „buvo žmogus išmintingas, arielkos nẻ ị burną neimąs, ne brangininkas ir valgyt išmonių nedarąs" (Valančius 2001, 127). Panašiais epitetais apibūdindamas, Valančius pristato ir būsimą Stapono žmona Morinę: „,vedè padorią ir dievobaimingą mergelę" (Valančius 2001, 127). Išvardyti teigiami būdo bruožai ir teisingi veikèju ịpročiai rodo autoriaus nusistatymą sutuoktiniu gero gyvenimo klausimu. Tarpusavio santarvei padeda ne tik abiejų sutuoktinių dievobaimingumas, kuris buvo būtinas, kuriant patvarią šeimą (,Pats su savo moteria Jonke kas mėnesį èjo spaviednès“, Valančius 2001, 225), bet kartu nemažą reikšmę, Valančiaus įsitikinimu, turejjo ir veikejjų išsimokslinimas, buvimas raštingais. Panašu, kad autoriui gebejjimas skaityti buvo svarbus veiksnys geriems santykiams palaikyti - šeimoje kartu skaitomos knygelès, dažniausiai religinio pobūdžio, buvo garantas darnai tarp vyro ir žmonos palaikyti: ,,Jūzupas skaitė visiems girdint „Žyvatą Viešpaties Jėzaus“, „Žyvatus šventųiu“, „Pradžią““ ir kitas knygeles, kurių daug turejo“ (Valančius 2001, 225). Taip autoriaus norèta ne tik parodyti geros šeimos pavyzdį, bet ir išugdyti apsišvietusius katalikus. Anot Valančiaus, laimingą sutuoktinių gyvenimą lemia ir adekvatus elgesys susipykus, t. y. mokejjimas teisingai elgtis vienam su kitu konfliktinèse situacijose: ,Jūzupas niekuomet nesibarè su moteria, pamatęs ją pyktį metantis, lipšniai prabilo ir beregint ją nutildè. Jonkẻ taipogi pamačiusi vyrą apmaudingą, tylèjo kaip žuvis prūde, niekuomet jam atkakliai nè žodžio neatsakè. Taip abiem pusèm norint vienybëje būti, niekuomet iš tiesu nesusibarè, niekuomet neatėjo ligi keršto“ (Valančius 2001, 225) (,Padorus ūkininkas“, „Paaugusių žmonių knygelë“). Šioje citatoje atsispindi paties Žemaičių vyskupo požiūris ị konfliktinę situaciją tarp sutuoktinių, paminint atveji, kai jam pačiam teko taikyti savo sūnėną Vladislovą Beresnevičiu su jo žmona Bronislava. Tuomet Valančius laiške ragino sūnėną kaltinti ne tik žmonos, bet ir savo būdą, patare pirmam nusileisti ir pakviesti grịžti pas motiną pabėgusią žmoną (Merkys 1999, 185). Nepaisant išreikšto skatinimo nepamiršti ịsipareigojimų šeimai ir vienodai prisiimti atsakomybę konfliktinejje situacijoje, šioje citatoje įžvelgiamas ir 
šioks toks skirtumas, kas yra patartina vyrui ir kas moteriai - vyras gali lipšniai kalbèti, o moteriai geriausia visiškai patylèti. Tai viena iš sąlygų, kurias vèliau Valančius išplètos rašydamas savo testamentini laišką. Abiejų tèvų atsakomybė auklèjant vaikus, akcentuojant žmonos vaidmenį, aptinkama Valančiaus kūrinyje „Pranciškus Bielskis“ („Vaikų knygelè"): „Pats (bajorèlis Bielskis) apie jo (sūnaus) gerą išauginimą šylès, bet juoba dar dievobaiminga jo moteris Bielskiené. Vaikus savo, dar tebšvelpiančius ir vos pavelkinai žodžius ištariančius, mažne kas vakarą, ị rinkį sustačiusi, mokẻ poterių, prisakymų ir sakramentų“ (Valančius 2001, 107). Šiame ir kituose kūriniuose autorius parodo, koks svarbus yra vaikų religinis auklejjimas ir kartu jų rengimas šeimai.

Valančius, kuriam labai rūpejo jam pavestųjų žmonių dora ir apšvietimas, ypatingą dèmesį skyrẻ savo parapijiečių blaivybei. Blaivybės idejjas vyskupas skleidẻ savo ganytojiškaisiais raštais ir didaktiniais kūriniais. Visur, kur aprašomi teigiami veikejai ir darnios šeimos pavyzdžiai, aptinkame svarbų tų veikejų apibūdinimą, kad pastarieji negèrè ,arielkos“. Valančius akcentavo ne tik blaivybės naudą, bet ir žmogaus darbštumą bei susiturèjimą nuo nereikalingų, laiką gaišinančiu pažinčių ir tuščių kalbų, turgų pristatydamas kaip abejotino naudingumo ir reputacijos erdvę: „Staponas gerai išdirbdavo žemę, todèl rugiai, javai ir linai visuomet jo derèjo, arielkos niekuomet ị burną neèmé, ị turgus panedèliais ị Raseinius retai tevažiavo, o nuvažiavęs lig laiku namon grịžo. Pažǐstamiems norint Raseiniuose užtūrèti, paprastai sakydavo: „Susiedaliai, ką atvežiau - pardaviau, ko reikalavau - pirkau, namuose turiu darbo, ko aš beturèčiau čia trukti ir ašvienius savo badu stapinti?" Taip atsakęs sẻdo ị ratus ir važiiavo namon" (Valančius 2001, 243). Šitokio nusistatymo ir elgesio rezultatas - namuose jo laukianti geranoriškai nusiteikusi sutuoktinè: „Kotryna parvažiuojantị visuomet blaivų su ištiestomis rankomis priimdavo ir tuojaus vadindavo prie šilto, tyčiomis užlaikyto valgio“ (Valančius 2001, 243). Valančius kaip ir daugelyje savo tekstų, pabrèždamas darnios šeimos svarbiausius kriterijus - lygiateisiškumą, blaivumą ir darbštumą, parodo, kad ir Stapono žmona savo elgesiu neatsiliko nuo vyro: „,Taip vyrui dailiai elgiantis, ir Kotrynė netopsojo rankas susinèrusi“ (Valančius 2001, 245). Visa tai lemia ne tik darną šeimoje, bet ir pasiturintị gyvenimą. Net ir netikęs gyvenimo būdas, kurị buvo pasirinkusi Petronèlè iš apsakymo „Petronè ir jos priepuoliai“ („Paaugusių žmonių knygelë“), neužkerta kelio laimingai santuokai ir gražiam sugyvenimui su vyru, jeigu tik gailimasi dèl savo nedoro elgesio ir pasiryžtama keistis (Petronèlei, kuri iš pradžiu buvo laisvo elgesio mergina, jai atgailavus ir pakeitus gyvenimo būdą, pasiseka ištekèti už gero vyro, nes, kaip rašoma kūrinyje, pasikeitusi „Petronèlè labai dailiai elgès“ ir „Laimino aniedviem Viešpats: turẻjo gan duonos ir pavilgos, vaikai gražūs, ị motiną pavẻdūs augo, matušès klausè“, Valančius 2001, 271). Taip iš neigiamos veikèjos virtusi teigia- 
ma, Petronèlè galėjo džiaugtis visais gero gyvenimo ir darnios šeimos privalumais. Beje, galima būtų paminèti, kad tokių „pasitaisymo“ galimybių Valančius savo herojams duoda nedaug. Yra vos keletas apsakymų, kuriuose netinkamai pasirinkę ar pasielgę veikejai atgailauja ir sulaukia gražaus ir darnaus gyvenimo. Daugeliu atveju (taip pat ir apsakyme „Petroné ir jos priepuoliai“) autorius nurodo ir tapimo neigiamu veikejju priežasti - tai netinkamas auklèjimas vaikystèje. Taip Valančius dar kartą atkreipia sutuoktinių demesị į tinkamas vaikų ugdymo ir auklèjimo sąlygas, akcentuodamas vertingą gero pavyzdžio galią.

\section{Nedarnūs sutuoktinių santykiai}

Dažniausiai, kaip būdinga didaktiniam kūriniui, pamokančiai istorijai, sužlugęs gyvenimas, mirtis, nesutarimai - tai blogo elgesio pasekmè. Kaip pavyzdys paminètinas apsakymas „Jurgis nedoras ūkininkas“ („Paaugusių žmonių knygelè“). Kūrinyje aprašomi abu sutuoktiniai, geriantys degtinę. Vaizduojama šeima - visiška priešingybe šeimoms, kuriose vyrauja bendradarbiavimo dvasia ir santarvè. Nors Valančius sutuoktinių sutarimui šeimoje apibūdinti pateikia daug kriterijų (darbštumas, atsakingumas ir pan.), vis dèlto svarbiausiu kriterijumi jis laiko alkoholio nevartojimą ir tikybinių požymių atitikimą. Štai minètame kūrinyje „Jurgis nedoras ūkininkas“ šeimoje ir vyras, ir žmona abu geria degtinę (,arielką“). Girtavimą autorius laikẻ žmonių nelaime, moralinės ir fizinės degradacijos priežastimi. Todẻl ir sutuoktinių konfliktiški tarpusavio santykiai, skurdi buitis išryškejjo kaip girtavimo pasekmè: „Pakrūmèj, nutrūkusioj butoj, gyveno vyras su moteria, Jurgis su Morta. Abudu gebejo gerti, abudu buvo piktu, abudu pešès ir mušès vos ne kožną dieną“ (Valančius 2001, 233). Suprantama, tokioje nedarnioje ir problemiškoje šeimoje nukenčia ir vaikų auklèjimas: „Bet kaip galèjo padoriai išauklèti motina, vos ne visuomet girta?“" (Valančius 2001, 233) Apsakyme akcentuojama, kad geriančiu porų santykiuose neišvengiamas smurtas prieš žmoną ir vaikus: „sugrižo girtas ir pradejo čaižyti su botagu per ienas ir per arklius. Kliuvo motinai ir sūnui“ (Valančius 2001, 237), ir vèliau: „Jurgis sugrižo namo girtu girtas ir pradejjo mušti savo moterį“ (Valančius 2001, 239). Kaip minèta, Valančius savo didaktiniuose kūriniuose pamokymui dažniausiai vaizduodavo, kokị atlygị už savo gerą ar nederamą elgesị sulaukia kūrinio veikẻjas. Jei elgesys smerktinas, kaip šiuo atveju, tai ir pasekmès būna liūdnos, t. y. veikejjų laukia visiškas skurdas, o dažnai - ir nelaiminga mirtis: „Darbininkams maž tekliuvo [arielkos $-S$. B.], bet pats su pačia būtinai apsigèrè. Nesitikètai kilo tarp anųdviejų barnis, vyras šlavè su vėzdu moteriai, ši brinkt ir parvirto. $<\ldots>$ Jurgienẻ iš to įsirgo, vedẻ kunigą, spaviedojos, gulejjo dvi nedèli ir miré“ (Valančius 2001, 239). Panašaus galo sulaukia ir pats Jurgis: jis randamas miręs pakelès 
krūmuose, o palaidojamas be bažnyčios apleistuose kapuose. Tẻvų pavyzdžio auklèjamas, jųdviejų sūnus taip pat buvo linkęs išgèrinèti. Todèl jam nepasiseka nei sukurti šeimos, nei susitvarkyti savo gyvenimo.

Pavojų geriems tarpusavio santykiams tarp žmonos ir vyro Valančius ižzvelgẻ ir skirtingoje tikyboje. Ypač daug mišrių santuokų Valančiaus vyskupavimo pradžioje buvo Kurše. Ten dèl liuteronų dominavimo šeimos katalikiškoji pusė buvo linkusi pasiduoti liuteroniškosios pusès įtaigai. Todẻl svarstant skirtingų tikẻjimų santuokų klausimą Valančius įsake griežtai laikytis Bažnyčios įstatų (Alekna 1975, 39). Apsakyme „Tryne ir Vicentas“ vaizduojama religiniu požiūriu mišri santuoka - kataliko ir protestantès. Nè vienas iš jų nenori atsisakyti savo tikybos, vildamiesi, kad kažkuris iš sutuoktinių perims kitos pusès tikejjimą ir religines tradicijas. Šiuo atveju autoriui svarbu ir protestantų, ir katalikų tikejjimą išpažistančiojo pozicija. Anot Valančiaus, šis skirtingumas lemia nesutarimą ir konfliktus šeimoje, pradedant maisto ruošimu (,taip vienuose namuose pasidarẻ dvi vieri, dvejoki valgiai“, Valančius 2001, 281), švenčiant šventes, samdant šeimyną ir, tai itin svarbu, sprendžiant vaikų auklejiimo problemas. Pirmosios problemos iškilo krikštijant vaikus, vèliau mokant juos tikybos dalykų. Konfliktų šeimoje kilo ir dèl katalikiškų švenčių šventimo bei vyrui norint pasninkauti. Nemažą vaidmeni šiuose santykiuose vaidino ir žmogaus būdas bei charakteris. Autorius užsimena, kad nors Vicentas ir tvirtai laikèsi katalikų tikejjimo, tačiau jis buvo lètas, todẻl ir nepajėgè nukalbėti savo žmonos ar pakeisti jos nusistatymą tikybos atžvilgiu. Gimus dukteriai, ši pakrikštijama pagal protestantišką tradiciją, o Vicentas negali tam paprieštarauti. Sutuoktinių santykius geriausiai apibūdina Vicento tèvas: „,sutinkata it dalgis su akmeniu, mylitos kaip kate su šuniu, gerai, kad nesimušata“ (Valančius 2001, 281). Artejjant Velykų šventėms, Kotrẻ su dukteria palieka savo vyrą ir sūnų, kuris buvo auklëjamas katalikiškai, ir išvyksta i Kuršą. „Isirūpinęs Vicentas verkè ir, bučiuodamas savo sūnų, tarè: „Vaikali, aš pasilikau gyvanašlis, tu našlaitis, matušè tavo kaži kur padingo“ (Valančius 2001, 283). Vicentui su sūnumi taip pat išvykus, grižusi Kotrynè ir neberadusi vyro išgyvena, verkia ir jaučiasi nelaiminga. Valančius kūrinio gale pateikia pamokančią išvadą: ,Taip dvi vieri, vienuose namuose patalpinti, tuos išgaišino, o vyrą su moteria nelaimingais padare““, todèl, teigia autorius, ,tegul bus pamokslu visiems katalikams, ketantiems nekatalikes vesti, ir katalikẻms, norinčioms už nekatalikų tekèti“ (Valančius 2001, 283). Valančius ta pačia tema yra parašęs dar vieną apsakymą - „Janis Kuisis“. Autorius nurodo, kad vis dèlto yra galimybė, nors ir labai nedidelè, kad skirtingų tikejjimų pora gyventų darnoje, tačiau tam reikia, kad kitatikis būtų atverstas ị katalikų tikejjimą. Bet tam būtinas stiprus būdas ir išsimokslinimas: „Kad Jonis būtų buvęs stipresnis ir juoba, nekaip Uršulè, mokytas, tikrai ta būtų pervirtusi į liuterkas, bet kad ta buvo stipresnè ir 
protingesnè už Joną, dèl to tai visus namus ị katalikus perverte்“ (Valančius 2001, 291). Nepaisant šios istorijos laimingos baigties, autorius perspėja, kad visada yra pavojus vesti ar tekèti už žmogaus ne savo tikejjimo.

Valančius pavojų laimingai santuokai ir netgi paties žmogaus gerovei įžvelgia ne tik skirtingų tikejjimų, bet kartu ir skirtingų tautybių žmonių santykiuose. Ypač aktualu tampa vedybos su rusų tautybės asmeniu. Merkys pažymi, kad Katalikų Bažnyčios ardymas sustiprèjo per mišrias tikybiniu požiūriu santuokas. Rusų administracija griežtai žiūrẻjo, kad katalikų ir stačiatikių tikybų jaunieji tuoktųsi vien cerkvejje, o stačiatikių perejjimas ị katalikybę buvo griežtai draudžiamas. Vienoje brošiūroje Valančius įspejo mergaites, kad „netekètų už rusų, nes tuo pražudysiančios pačios save ir savo vaikus“ (Merkys 1999, 590). Tai gana vaizdžiai atsiskleidžia kūrinyje „Agate““ („Paaugusių žmonių knygelë). Apsakyme lietuvaitė Agate pamilsta rusų kareivị Nikiporą ir nutaria už jo ištekèti, nepaisydama tėvų perspejjimų ir draudimų. Čia susitinka ne tik skirtingų tautybių, bet ir skirtingų tikybų - katalikų ir stačiatikių - asmenys. Autorius kūrinyje jau nebedetalizuoja poros tarpusavio santykių, o tiesiog po truputi atskleidžia, kaip ir kokie įvykiai, vargai sugriauna žmogaus gyvenimą. Agatė, nors galbūt buvo mylima vyro, tačiau kareivis, kuriam svarbiausia yra jo tarnyba, neturi ko pasiūlyti savo moteriai: ji turi gyventi kartu su kitais kareiviais, net ir būdama nëščia eiti pėsčiomis didelius atstumus. Galu gale Nikiporas ją po nesèkmingo gimdymo palieka vieną ir išeina toliau savo tarnybos reikalais. Dar daugelị vargu išvargusi, Agatė numiršta skursdama, ligota ir visų apleista. Valančius visu savo kūriniu iliustruoja tai, ką kūrinio gale pasako kaip moralą: „Iš tiesų ne kartą regim ištekant mergeles mūsų už maskolių, bet niekuomet nematom ištekèjusiu laimingomis“ (Valančius 2001, 299). Šia istorija autorius metonimiškai apibendrina daugeli kitu panašių gyvenimo istorijų, tuo akcentuodamas vedybų su rusų tautybès asmenimis netinkamumą: „Todèl kuri mergaitè turi proto, lai su maskoliais nesipainioja“ (Valančius 2001, 299). Šiame kūrinyje parodoma moters istorija, kuri buvo palikta vyro. Tačiau neabejotinai Valančiui buvo žinomos ir kitos už rusų ištekèjusių lietuvaičių istorijos, kai būdamos katalikès, jos buvo visiškai priklausomos nuo vyro ir ujamos, o turedamos laikytis svetimos tikybos, savąią apleisdavo. Tad Valančius, atskleisdamas tokių santuokų neigiamas pasekmes, ne tik rodè savo nusistatymą dèl svetimos tautybès, bet ir priešinosi „Stačiatikių Bažnyčios ekspansijai, skatinamai valstybinès valdžios“ (Merkys 1999, 590).

Kaip sutuoktiniams bendrauti, Valančius moko ir testamentiniame savo laiške „Testamentine gromata“, paskelbtame 1894 m. „Žemaičiu ir Lietuvos apžvalgoje“. Laiške autorius rašo: 
Yra nemažai moterysčių gerų, kuriose vyras su moterimi, taikiai gyvendamu, daro laimingus vienas antrą, vaikus ir šeimyną. Bet yra taipogi negerų, kuriose barasi vyras su moterimi. Užvis tai atsitinka tuokart, kada vyras ar abudu yra girtuokliai. Pasigèręs ar atkaklus vyras ne vien pakelia barnius, bet dabar kartais muša savo moterị. $\langle\ldots>$ kiekvienas gaspadoriau, atmink, jogei moteris yra tai kūnas tavo $\langle\ldots\rangle$, yra artimiausia prietelka: nepadaryk karčiomis dienų jos, ydas pakelk, nes ir tu nemažai ju turi. Matydamas supykusią, užtylèk, būk anai ištikimas, skaityk ją už sau lygią ir nieko nepradèk dirbti, su ja pirma nepašnekèjęs. Moteris, matydama vyrą girtą, nestirveliok, nelįsk į akis, bet būk lipšni, duok jam valgyti ir paguldyk, nes jisai tuokart yra beprotis, o su bepročiu bardamos gali gauti ko nenorėdama. Atmink, jogei vyras yra tau artimiausias žmogus visame pasaulyje. $<\ldots>$ Todèl sueję i ́ porą, taip elkitès, idant niekuomet nesusibartumète, idant vienas antram tikrai širdies neužduotumèt, nes toks yra prigimimas žmogaus, jogei, jei kas vieną, antrą ir dešimtą kartą tikrai užlies už kailio, ịkyrès, to jau niekuomet nebegali širdingai mylèti“ (Vaižgantas 2002, 462-463).

Laiške išdèstytos sąlygos ir pamokymai, kurie buvo implicitiškai išreikšti grožiniuose kūriniuose, kaip reikia elgtis, kad bendras gyvenimas būtų darnus, kad šeimoje vyrautų santarvè ir tarpusavio pagarba.

\section{Išvados}

Šiame straipsnyje buvo išanalizuoti devyni Valančiaus didaktiniai kūriniai, kuriuose aprašomi sutuoktinių tarpusavio santykiai. Valančiaus kūrinių analizė rodo, kad Žemaičių vyskupas puoselejo lygiateisiškumo ir bendradarbiavimo šeimoje idèjas. Galima būtų pažymèti, kad vyro ir moters šeimoje lygiateisiškumo idejos skleidimas tuo laikotarpiu buvo novatoriškas. Valančiaus šeimos samprata buvo kitokia, ne kaip tuomet buvo ịprasta. Suprantama, moters lygiateisiškumas šeimoje skelbiamas kartu nurodant ir tam tikras jai priklausančias pareigas. Viena iš svarbiausių pareigų, kurią prisiimti taip pat buvo raginamas ir vyras, - tai tinkamas vaikų auklèjimas, kurio dominantė buvo religinis ugdymas. Atliktas tyrimas taip pat parodè, kad sutuoktinių lygiateisiškumas ir darna šeimoje įmanomi tik laikantis socialinių-luominių, tikybinių ir tautinių-kultūrinių požymių atitikimo. Nors Valančius nelaikè skirtingų luomų rimta kliūtimi santuokai, tačiau jis mokè skaitytojus sutuoktinius rinktis iš savo socialinès aplinkos darnai šeimoje užtikrinti. Kūriniuose atskleisdamas konfliktinių situacijų šeimose atvejus, tikybinį atitikimą autorius laikė vienu svarbiausių požymių laimingai santuokai sukurti. Perspėdamas dèl tikybinio vienodumo, Valančius taip pat išreiškè pasipriešinimą Stačiatikių Bažnyčios ekspansijai. Darniems santykiams palaikyti vyskupas akcentavo blaivybę, darbštumą ir išmintingumą, pirmenybę teikdamas 
blaivybei, nes tik blaivus žmogus gali tinkamai pasirūpinti savo artimuoju, savo nuosavybe, savimi ir savo gyvybe.

Atliktas tyrimas parodè, kad Valančius savo kūriniuose veikèjus, kaip ịprasta didaktinei literatūrai, griežtai skirsto į teigiamus ir neigiamus. Būtent kūriniai su teigiamais veikejais prisideda kaip darnios ir harmoningos šeimos pavyzdžiai, o kūriniai su neigiamais veikejais - kaip pamokymas ir pavyzdys apie nedarnius ir smerktinus vyro bei žmonos santykius.

\section{Literatūra}

Alekna 1975 - Antanas Alekna. Žemaičiu vyskupas Motiejus Valančius. Su Vinco Trumpos įvadu ir dokumentų priedais. Čikaga: Lituanistikos institutas.

Kavolis 2016 - Vytautas Kavolis. Moterys ir vyrai lietuviu kultūroje. Vilnius: Apostrofa.

Merkys 1999 - Vytautas Merkys. Motiejus Valančius: tarp katalikiškojo universalizmo ir tautiškumo. Vilnius: Mintis.

Trumpa 1975 - Vincas Trumpa. Motiejus Valančius - mokytas ir išmintingas žemaitis. In Antanas Alekna. Žemaičiu vyskupas Motiejus Valančius. Su Vinco Trumpos įvadu ir dokumentu priedais. Čikaga: Lituanistikos institutas, IX-XXX.

Vaižgantas 2002 - Vaižgantas. Motiejus Valančius. Pastabos pačiam sau. In Raštai, t. 14. Vilnius: Lietuvių literatūros ir tautosakos institutas, 285-484.

Valančius 2001 - Motiejus Valančius. Raštai, t. 1. Parengė Vytautas Vanagas. Vilnius: Lietuviu literatūros ir tautosakos institutas.

\section{Skaistė Barkutè}

\section{THE DEPICTION OF MARRIAGE}

\section{IN THE DIDACTIC PROSE BY MOTIEJUS VALANČIUS}

Summary

The article examines the didactic prose writings of Motiejus Valančius (18011875), the Bishop of Samogitia, a writer, and the organiser of a temperance movement. Valančius educated people through his sermons, letters and didactic prose. The article discusses the depiction of marital relationships in nine didactic prose writings. As the analysis reveals, Valančius developed a view of equality between a man and a woman in the family, and both parents taking responsibility for the children's upbringing. Equality in family relations applies to mutual decision making, the equal distribution of work, and social equality. For example, the characters in Valančius' tales take mutual decisions concerning the children's upbringing, and other important decisions concerning daily matters. Aspects of self-control and a tone of proper living ensure mutual consonance between a husband and wife. In order for the relationship between a husband and wife to be harmonious, it is necessary for both of them to be wise, abstinent, diligent and 
devout. Valančius taught readers how to behave in conflict situations. He suggested being patient, calm, and on some occasions to keep silent.

An analysis of Valančius' writings shows that the author encouraged readers to seek conformity in the social, cultural and religious aspects of both spouses. For this reason, Valančius described in his writings how religious incongruity destroys family life and happiness. The Bishop of Samogitia saw a threat to a happy marriage, and even to a person's welfare, in relationships between different nationalities. It was a matter of great relevance when the writer talked about marriage to people of Russian nationality. Valančius emphasised that the relationship between a man and a woman was destroyed when they were drunk. The bishop was convinced that debauchery was a human disaster, a cause of moral and physical decline. Therefore, in his didactic prose, a conflict-ridden relationship between spouses, and a poor everyday life, was shown to be the result of debauchery.

The analysis of Valančius' didactic prose shows that the writer divided characters strictly into positive and negative ones. Tales with positive characters were examples of a good and harmonious relationship in the family. Tales with negative characters gave examples of unharmonious and bad behaviour by spouses. It should be noted that the dissemination of the ideas of equality between a woman and a man in a family was rather innovative for these times. 